\title{
Rojaliści i Krasnoludki wychodzą na ulicę. Kultura kontestacji w działaniach ruchu České děti i Pomarańczowej Alternatywy
}

\begin{abstract}
Balcerzak Małgorzata, Rojaliści i Krasnoludki wychodza na ulicę. Kultura kontestacji w działaniach ruchu České děti i Pomarańczowej Alternatywy (Royalists and Dwarfs Take to the Streets. Culture of Resistance in the Activities of Movements of Czech Children and Orange Alternative). „Poznańskie Studia Slawistyczne” 6. Poznań 2014. Publishing House Science and Innovate, pp. 17-32. ISBN 978-83-63795-51-1. ISSN 2084-3011.

This article is an attempt to compare two contestation models, that occurred in the activities of new social movements formed in the 80s of the twentieth century in Czechoslovakia and Poland (Czech Children and Orange Alternative). Both movements are the examples of the changes taking place in the process to form of political and social opposition to the communist regime. The article describes the relationship between political commitment and understanding of the aesthetic function (influence of surrealism) in the culture of opposition.
\end{abstract}

Keywords: surrealism; power and identity; culture of resistance; politics and aesthetics; Orange Alternative; Czech Children

Na ulici člověk vidí/plno lidí

Nebot' je vice práce/proto je ta láce Esenbák i jeho rodina/se modlej za Stalina Ale jestli prijidou mrazy/všecko se zkazi!

Egon Bondy, Vánoce

Wszyscy proletariusze, bądźcie piękni! Pomarańczowa Alternatywa

„Jesteśmy specjalistami od Buntu. Nie ma takiego środka działania, do jakiego w razie potrzeby nie bylibyśmy zdolni się uciec" (Ważyk 1978: 12). Wbrew pozorom nie jest to wyznanie zaangażowanych politycznie rebeliantów, a jedynie ósme przykazanie z Deklaracji biura poszukiwań surrealistycznych, podpisanej w 1925 roku przez grupkę miłośników sztuki. 
W tym samym dokumencie proklamowali: „Nie staramy się nic zmienić w obyczajach ludzi, ale chcemy im ukazać kruchość ich myśli, i na jak chwiejnych podstawach, nad jakimi lochami zbudowali swoje trzęsące się domy” (Ważyk 1978: 12). Sześćdziesiąt lat później człowiek o mało artystycznym pseudonimie Major pisał: „Jedyne rozwiązanie na przyszłość i dzisiaj to surrealizm (...). Przecież cały świat jest dziełem. Już pojedynczy milicjant na ulicy to dzieło sztuki" (Fydrych, Dobosz 1989: 11). Ten sposób obrazowania nie był jednak wyłącznie ludyczną prowokacją. Przedmiotem przywołanej gry słownej stała się żywa forma kontestacji, której celem było wypracowanie niezależnej sfery myśli i sztuki, zaanektowanej przez apologetów, „żabiej perspektywy"1.

W latach osiemdziesiątych XX wieku dwa nowe ruchy społeczne, České děti i Pomarańczowa Alternatywa stosowały opór wyrażający się w barwnych odmianach (a)politycznego uczestnictwa. Był on znakiem zerwania z wyobrażeniem tradycyjnej opozycji, czego przykładem stały się przewrotne deklaracje przedstawicieli obu grup: „Největší legrace je, když to člověk myslí vážně” (Placák 2012) lub „Człowiek nie jest z marmuru ani z żelaza" (Fydrych, Dobosz 1989: 13), trawestujące puszczone w oficjalny obieg hasła („Pisarze do pióra, studenci do nauki, pasta do zębów”; Engelmayer 1990: 26). Nie bez przyczyny w tych i podobnych im formach kontestacji rzeczywistości politycznej następowało sprzężenie dwóch komponentów - elementu demos ${ }^{2}$ z potrzebą sztuki. Idąc tropem wyznaczonym przez Jacques'a Rancière'a, można zauważyć, że estetyka, uczestnicząca w regulacji trzech podziałów (czasu i przestrzeni; tego, co widzialne, z tym, co niewidzialne oraz języka), zbliża się do ,ppolityczności” (Rancière 2008: $68)^{3}$. Następuje fuzja porządków, które miały być wyraźnie rozgraniczone.

Działania „burzycieli”, wywodzących się z opisywanych ruchów i nie godzących się na zajęcie określonego miejsca w obrębie wyznaczonej

1 Pojęcia tego używam jako znaku rozpoznawczego sztuki socrealistycznej, nakierowanej na wywołanie wrażenia monumentalizacji obiektu (np. przez stosowaną w fotografii technikę tzw. rzutu z dołu) (cf. Włodarczyk 1989: 18).

2 Mam tu na myśli wpływ ruchów na budowę społeczeństwa obywatelskiego, a zatem społeczno-polityczny aspekt ich działalności.

3 Polityczności rozumianej szeroko jako kategoria dotycząca ,tego, co widzimy i możemy widzieć”, „tego, kto ma kompetencje i predyspozycje, aby mówić”, „sposobów zajmowania przestrzeni lub dysponowania czasem" (Rancière 2008: 68). 
przestrzeni władzy, były powiązane z ich artystyczną proweniencją. Pomimo widocznych różnic w poszczególnych formach oporu, wyrażały tę samą potrzebę przekroczenia zastanego porządku rzeczy. Absurdy rzeczywistości „normatywnej” stały się mechanizmami wyzwalającymi stosowane przez nich praktyki. Claus Offe, zderzając paradygmaty określające cechy klasycznych i nowych ruchów społecznych, wskazuje na elementy, które są właściwe omawianej transgresji: działanie w imieniu szerszej zbiorowości, ochrona wartości (autonomia i tożsamość), spontaniczność i polityka protestu (Offe 1995: 225). Efektem tego porównania jest (co prawda niezgłębiany, lecz sugerowany przez socjologa) problem ze ścisłym definiowaniem tego typu form społecznego uczestnictwa - z jednej strony, funkcjonuje pojemna etykieta ,ruchy alternatywne”, z drugiej, oparte na etosie buntowniczym, hasła ,polityka nieporządku” lub „neoromantyzm”. Zwłaszcza to ostatnie pojęcie ożywia mityczną (bo odwołującą się do stereotypu romantycznego buntownika) aurę kultury oporu. Na ten aspekt zwraca uwagę Wojciech Burszta, pisząc, że ,kontrkultura i jej syjamska bliźniaczka - kontestacja” znajdują się bliżej ,legendarnej opowieści albo nostalgicznej ewokacji” (Burszta 2005: 219).

Dlaczego więc omawiany polityczny protest zróżnicowanych, choć niezwykle żywotnych w podobnych warunkach historycznych, modeli (reprezentowanych przez polską ,pomarańczową” kulturę i czeski ruch pokolenia młodych dysydentów) łączy „surrealizm” (rozumiany nie tylko jako kierunek artystyczny, ale pewien wariant kultury kontestacji, czerpiący swoją siłę z estetycznego potencjału)? Mówiąc najprościej - poetyka protestu, bazująca na absurdzie, stanowi odpowiedź na niedorzeczną codzienność, z jej nonsensowną biurokracją i dyktaturą ,normatywności”. Można odwołać się do klasyka, którego słowa wskazują na iluzję potocznie ujmowanej ludyczności (,vtip je útok a obrana; je to projev převahy i zbraň slabšího”; Čapek 1984: 11), a zatem na możliwość wykorzystania surrealistycznej gry i humoru jako oręża w walce o własną autonomię. Deklaracja artystów odsłania performatywny wymiar sprzeciwu, wyrażanego w przestrzeni ulicznej: „Wolna sztuka jest jedyną i najbardziej niebezpieczną sztuką walki z rzeczywistością rzeczy i rzeczywistość o tym wie” (Fydrych, Dobosz 1989: 24).

${ }^{4}$ Offe wymienia więcej propozycji: ,nowe ruchy protestu”, ,nowa polityka”, ,,nowy populizm”, ,antypolityka”, „nieortodoksyjne zachowania polityczne” (Offe 1995: 229). 
Innej wskazówki dostarcza „dziedzictwo” buntowników - artystyczne środowisko, z którego wyrośli. W przypadku przedstawicieli Českich děti jest nim underground $\mathrm{z}$ otoczonym legendą Egonem Bondym (początkowo nawiązującym do dadaizmu i surrealizmu). Dla Pomarańczowej Alternatywy źródłem inspiracji są teksty francuskich surrealistów, wielokrotnie cytowane podczas happeningów, o czym zaświadcza inny fragment odezwy: „Strajk jest przejawem artystycznego gniewu o skomplikowanej strukturze gramatycznej”" („Pomarańczowa Alternatywa” 1981a: 1).

\section{České děti: powrót króla}

„Chłopcy i dziewczęta, kochacie niebezpieczeństwo? Chcecie poznać świat demonstracji, tajnych spotkań, niewidzialnego pisma i podziemnych korytarzy? Wstąpcie do Czeskich dzieci” („Koruna” 1989c: 10). Takie hasło reklamowe, umieszczone pomiędzy zdjęciem Charlesa Bronsona a wizerunkiem Marilyn Monroe, pojawiło się w czasopiśmie nieprzypadkowo w swej nazwie odwołującego się do symbolu monarchii. Tam też w 1988 roku ukazał się manifest wywołujący spore zamieszanie. Pozostawiał wiele miejsca do interpretacji (mógł zostać odebrany jako polityczny żart czy prowokacja albo też poważna odezwa, zachęcająca do rewolucji) i ujawnił dezorientację władzy, która zezwoliła na przedruk tekstu w piśmie „Rudé Právo". Manifest opublikowano w dwóch wersjach językowych (czeskiej i łacińskiej), opatrzonych nagłówkiem Bohemorum liberorum declaratio:

My, České děti, vyhlašujeme, že Svatováclavská koruna, České království trvá. Připravujeme se na příchod nového krále, což je náš nejvyšší cíl.

Král z boží milosti je Bohu odpovědný za svou zemi a za svůj lid!

Král je záštitou slabých proti mocným a bohatým!

${ }^{5}$ W definicji surrealizmu Antonina Artauda można odnaleźć kilka podobnych (opartych na poetyce absurdu i prowokacji) punktów stycznych z deklaracjami Pomarańczowej Alternatywy: ,jest [surrealizm - M.B.] natomiast sposobem całkowitego wyzwolenia ducha i wszystkiego, co do niego podobne”; ,połączyliśmy słowo SURREALIZM ze słowem REWOLUCJA jedynie po to, aby uwydatnić bezinteresowny, oderwany i właściwie zupełnie beznadziejny charakter tej rewolucji”, „,na każdym zakręcie myśli Społeczeństwo nas odnajdzie” (Ważyk 1978: 13). 
Král je záruka, ochraňuje lesy, zvěř, přírodu proti vládnoucím kriminálním živlům, bez nejmenšího pozastavení loupícím a ničícím poklady země, aniž by zemi to, co jí vzaly, nahradily! (Placák 1989: 2).

Karta poprzedzająca proklamację nawiązywała do monarchizmu, umieszczono na niej nagłówek z pracy Nejvyšši ochránce českých děti, jeho veličenstvo císár a král František Josef I (1913). Dokument, będący nieinstytucjonalnym (bo łączącym dowcipną formę z antyustrojową odezwą) sposobem wyrażenia sprzeciwu, wywołał konsternację: wprawdzie miał on formę żartu, ale mógł sprowokować do wyjścia na ulicę i rozpoczęcia demonstracji. W rękach spadkobierców czeskiego undergroundu pojawiło się, $\mathrm{z}$ jednej strony, potężne narzędzie walki - wyostrzona ironia, z drugiej, jak opisywała bohaterka ruchu, Anna Hradilková, sama nazwa ugrupowania sugerowała, że „coś odziedziczyliśmy, że mamy wspólne korzenie, wspólną historię. Jest to coś, w czym się wzrasta, co na nas wpływa, co stanowi integralną część naszego istnienia" (Svodobová (red.) 1995: 12). Pojawia się zatem czynnik potrzebny do wzmocnienia poczucia wspólnotowości. Miejscem jej generowania jest ulica, która przecież podlega prawom panoptykonu ${ }^{6}$. Jak wskazuje Leszek Engelking, ,błazeński gest negacji, pogardy, szyderstwa i drwiny, małpiarski gest odrzucenia tylko z pozoru jest zabawny" (Engelking 2001: 90), ponieważ przedmiotem gry, w jaką uwikłana została władza, nie jest rozrywka, ale niewiara w system (który monopolizuje i „wiedzę”, i ,widzenie”). W szyderczym manifeście pojawia się wątek politycznego pluralizmu (jeśli nie „apolityczności”): „vláda nemusí mít, ba, nesmí mít žadný politícký program (...) je bud' dobrá nebo špatná” (Placák 1989: 3), ale przede wszystkim - element obywatelskiej decyzyjności, która ma być gwarancją władzy: „Královská vláda budiež taková, jakou sí zvolí lid" (Placák 1989: 3). Manifest stworzony przez historyka i pisarza (oficjalnie robotnika), Petra Placáka, podpisało 35 osób, wśród których znalazły się nazwiska ważne dla czeskiej kultury: Jáchym Topol, Luděk Marks, Andrej Stankovič, Ivan Martin Jirous („Magor”), Anna Hradilková,

${ }^{6}$ Również w obrębie ulicy obowiązuje reguła dyscypliny, przywołana przez Michela Foucaulta: „kto został umieszczony w polu widzenia i wie o tym, przejmuje na swe konto ograniczenia, narzucone przez władzę; dobrowolnie pozwala im wpływać na siebie, wpisuje się w relację władzy, gdzie odgrywa obydwie role - zostaje zasadą samoujarzmienia" (Foucault 1993: 244). 
Terezie Hradilková, Lucie Váchová i inni („Koruna” 1989b: 4). Logotyp ruchu przedstawiał znany symbol - czeskiego lwa z hasłem „Bóg, król i ojczyzna”. W grę wchodziła zatem potrzeba poszukiwania ,innej drogi” do wypracowania demokratycznej autonomii. Z jednej strony taką możliwość dawała perspektywa stworzenia ruchu o silnej więzi, wspieranej przez łączące uczestników podobne zainteresowania i cele, z drugiej - społeczny wyraz niezgody na pertraktowanie $\mathrm{z}$ władzą. Nie bez znaczenia pozostaje dziedzictwo podziemia - „,szyderstwo nihilisty” (Engelking 2001: 90). Placák po latach przyznawał, że opozycjoniści starszej generacji (związani z Kartą 77) „se obracejí na Husáka, na vedení státu. Že se chtějí bavit o lidských právech s režimem, který je postavený na popření veškerých lidských a občanských práv” (Placák 2006), zaznaczając odrębność ruchu: „My jsme se s naším prohlášením neobraceli na režim, ale na kamarády a širší veřejnost. A literární forma manifestu měla vyjádřit to, že ideologické cancy nás nezajímají a snaha «bojovat» za určité politické principy pro nás vždycky bude mít «svazácký» podtext" (Placák 2006).

Protestujący kierowali swój głos w stronę tradycyjnej opozycji, nie oczekiwali oznak skruchy ze strony władzy, chodziło im raczej o wyrażenie pokoleniowej postawy. Działalność Českých děti zapoczątkowały obchody „tygodnia Palacha”. Obecność aktywistów w czechosłowackiej przestrzeni publicznej nie należała zresztą do wyjątków, bo w tym samym czasie działały: SPUSA (Společnost přátel USA), Mírový klub Johna Lennona czy Kruh přátel polsko-československé solidarity ${ }^{7}$. Wspólnym elementem poszukiwaczy nowych dróg kontestacji stała się sfera muzyki, dająca pewną namiastkę niezależności. W biografiach ikon Českých děti widać to powinowactwo. Placák pisał teksty i „muzykował” w internowanym później zespole The Plastic People of the Universe, Topol wspierał brata Filipa w tworzeniu kapeli Psí vojáci. Poczucie odrębności,

7 Najstarszym ruchem, inspirowanym Kartą 77 był VONS (Výbor na obranu nespravedlivě stíhaných, 1978). Znaczenie działalności Solidarności Polsko-Czechosłowackiej we wzmacnianiu wzajemnych działań opozycyjnych, które z kolei owocowały akcjami obustronnego poparcia, m.in. dla ochrony więźniów politycznych (np. sprawa Petra Pospíchala) czy dystrybucji literatury w drugim obiegu, jest z pewnością nie do przecenienia. Jednak, z uwagi na chęć wyeksponowania alternatywnych form politycznej i społecznej opozycji, zasadniczym przedmiotem niniejszej analizy są inicjatywy ugrupowań słabo związanych z etosem ,solidarnościowym" (bez intencji obniżenia rangi tradycyjnych form kontestacji). 
powiązane z intencją wprowadzania zmian (również niewolną od młodzieńczego idealizmu), wielokrotnie przekładało się na swoiste odezwy, formułowane w postaci artystycznych fraz. Placák, w wydanym już w demokratycznych warunkach eseju Fízl, pisał ,jak se naučit překonávat sám sebe a strach, který se snaží člověka ovládnout a ztížit možnost svobodně se rozhodnout" (Placák 2007: 13). Autor Sestry natomiast ujmował motywację zmiany lirycznie, powołując się znów na kolektywne doświadczenie:

\section{Balada o neztracený generaci}

Jsme celkem

neztracená generace

jsme zkrátka a moudře

radost na pohled

my jsme ti skvělí

osumašedesátníci

co chtěli vypucovat svět

(Topol 1997).

Wydarzeniem jednoczącym członków ruchu České děti stał się pogrzeb jednego z przedstawicieli kultury oporu, Pavla Wonky. Manifest Tak dost! (1988), sformułowany przez Ivana Martina Jirousa w liście otwartym do władz państwowych, nie pozostawiał złudzeń co do postawy ,alternatywnej" opozycji, która odrzuciła eufemistyczną i kompromisową postawę Ludvíka Vaculíka, autora deklaracji Dva tisíce slov z 1968 roku. Poetyka tekstu „Magora” była pełna rozpaczy i nonkonformistyczna:

A pak jste zabili Pavla Wonku.

Pavla Wonku, vězně svědomí.

Je irelevantní, zda zemřel tím, čemu říkáte přirozená smrt, nebo utýrán vaším vězněním.

Tak dost!

Nejste-li schopni zajistit pro lidi, které vám justice dočasně svěřila, základní lidské právo, právo na život,

žádáme:

Okamžitě propust'te všechny vězně svědomí a všechny politické vězně! (Jirous 1988)

Pod petycją, opatrzoną listą ofiar reżimu, zgromadzono 271 podpisów, a jej autor zajął miejsce poprzedniego dysydenta (Wonky) w dokumentacji 
funkcjonariuszy bezpieczeństwa. Po aresztowaniu Jirousa jedną z inicjatyw Českých děti była kameralna, symboliczna w swej wymowie „pout’ za Magora" (demonstracyjna pielgrzymka, wyrażająca solidarność z zatrzymanym poetą). Dużo szerszy zasięg miała akcja protestacyjna, w której członkowie ugrupowania otwarcie domagali się poszanowania praw obywatelskich. Ważnym elementem demonstracji z 21 sierpnia 1988 roku stała się proklamacja, podpisana przez tysiąc manifestantów zgromadzonych na placu Wacława. Zawierała ona kilka jasno sformułowanych postulatów, m.in.: „pravdivé přehodnocení událostí roku 1968 a tzv. normalizace”, „zrušení cenzury”, „,dodržování základních lídských práv” („Koruna” 1989a: 21). Żądania inicjatorów ulicznych demonstracji, które, wbrew potocznej opinii nie miały tylko akademickiego charakteru, odsłaniają jednocześnie istotną zmianę, jaka nastąpiła w latach osiemdziesiątych XX wieku w Czechosłowacji. Słowo dysydent - dotąd wyjęte z publicznego dyskursu - nabrało egalitarnego charakteru, opuszczając obszar ,arystokratycznego” wykluczenia. To właśnie ono stało się znakiem rozpoznawczym przyszłych reform. Ugrupowanie České děti nie koncentrowało się na wąsko pojmowanej politycznej rewolucji, ale tworzyło grunt dla mobilizacji społeczeństwa obywatelskiego. W pamiętnym manifeście, obok zgoła „surrealistycznych” ustępów, wzbogaconych monarchistycznym tonem, pojawiały się również hasła powołujące inicjatywy ekologiczne czy wręcz antyglobalistyczne ${ }^{8}$. Niezależnie od starć z instytucjonalnymi przeciwnikami, sprawą najwyższej wagi było to, co na początku panowania reżimu komunistycznego nie mieściło się $\mathrm{w}$ pojęciu praktyki społecznej - „další chystáná shromaždění” („Koruna” 1989a: 21).

Podczas czechosłowackich obchodów dwudziestej rocznicy wkroczenia wojsk Układu Warszawskiego do Pragi, grupka aktywistów z Polski wraz z czeskimi przyjaciółmi podjęła inicjatywę „Bratnia Pomoc Wiecznie Żywa”. W jej ramach miało nastąpić uroczyste „,przekroczenie granicy” dzielącej dwa narody - jako miejsce spotkania wyznaczono schronisko na Śnieżce. Waldemar Fydrych, przywódca polskich „turystów”, „uważa ten sukces za moment wyzwolenia Czechów z kompleksu sławnej klęski pod Białą Górą"9 (Fydrych, Dobosz 1989: 90). Formuła zebrania stanowiła iro-

${ }^{8}$ Wyrazem tego zaangażowania była akcja „Stromovku nedáme!”.

9 W 1988 roku ,rewolucyjna grupa Wesoły Domek" przeforsowała autorski pomysł na polską Białą Górę w porozumieniu z Ruchem „WiR”. Tym miejscem był Gdańsk, gdzie połączono 
niczny komentarz do udziału polskiej armii w inwazji wojsk Układu Warszawskiego w sierpniu 1968 roku, co Major skwitował zdaniem: „Dobre imię Wojaka Szwejka zostanie ostatecznie uratowane", kończąc odezwę uroczystym „Vivat Pomarańcze. Praskie półkolonie 88” (Fydrych, Dobosz 1989: 91). Całości dopełniło oświadczenie powiązane $\mathrm{z}$ „manifestem represjonizmu":

19 sierpnia mija okrągła rocznica udzielenia bratniej pomocy Narodom Czechosłowacji, które opętane przez widmo rewizjonizmu w krytycznej sytuacji skorzystały z historycznej oferty - zaprosiły przyjaciół, wśród których nie zabrakło również naszych walecznych wojsk. Dały one skuteczny odpór nikczemnym knowaniom Dubczeka. (...) Po dwudziestu latach ponownie siły antysocjalistyczne zagrażają wielkiej sprawie (Fydrych, Dobosz 1989: 91).

\section{„Dlaczego aresztują krasnoludki?"10}

Pierwsze przykłady „malarstwa dialektycznego"11, artystycznej formy kontestacji materializmu marksistowskiego, pojawiły się na ulicach Wrocławia (dzielnica Biskupin) w nocy z 30 na 31 sierpnia 1982 roku. Były niepozorne, ale na tyle wymowne, że nikt nie miał kłopotów z umiejscowieniem ich symptomatycznego znaczenia w kontekście ,pionierskiego kierunku”: „Tezą jest napis, antytezą - plama, a syntezą - krasnoludek. Ilość przeradza się w jakość" (Warda 2010).

W ten sposób Pomarańczowa Alternatywa, z którą kłopot definicyjny mieli również przedstawiciele SB, łączyła język artystycznej rewolty z politycznym oporem, znajdując miejsce dla ocalenia własnej autonomii (bycie ponad politycznymi podziałami), przy jednoczesnym negowaniu status quo (sprzeciw wobec władzy monopolizującej wszelkie dziedziny życia), co nie było łatwe w obrębie systemu obarczonego bagażem politycznej

happeningi dotyczące kary śmierci z akcją „malarstwa surrealistycznego” (Frydrych, Dobosz 1989: 89-90).

${ }^{10}$ Pytanie zadane przez dziecko podczas jednego z happeningów Pomarańczowej Alternatywy (Warda 2010).

${ }_{11}$ Ten ironiczny termin to propozycja „Majora”, znak rozpoznawczy ruchu - krasnoludki pojawiające się ponownie na ścianach w miejscach uprzednio zamalowywanych z polecenia władz miasta. 
propagandy, wypełniającej przestrzeń codzienności. „Malarstwo społeczne”, wskazywał Fydrych, ,polega na sztuce dnia i nocy”, jej inicjatorem, ale i produktem miał być homo esteticus, ponieważ „najlepiej skierować zainteresowania na wyobraźnię" (realizując poniekąd, przyjęty w spadku po surrealistach, postulat: „Tylko wolność potrafi mnie jeszcze porwać”; Ważyk 1978: 15). Nie dziwi więc ustęp, zawarty w Małym Manifeście Surrealizmu Socjalistycznego, który uzupełnia postulaty odezwy właściwej z 1981 roku: „Działanie bez przemocy, wywołujące pozytywne skutki, jest to jedyne działanie godne zainteresowania prawdziwego człowieka dzisiejszej epoki. Człowieka, który nie jest już ponurym homo sapiens realizmu socjalistycznego, a rozwija formę Homo Esteticus Surrealizmu Socjalistycznego" (Frydrych, Dobosz 1989: 93). Stanowi ona wyznanie nie tyle politycznego banity, drwiącego z tego, co normatywne, ile przede wszystkim członka „prototypowego” społeczeństwa obywatelskiego. Major nie widzi szansy powodzenia dla innych form sprzeciwu - gra o wolność (która, jak przyznaje, ,jest komfortem”) toczy się przy wykorzystaniu całego ekwipunku, na jakim swoją stabilność opiera system, a zatem musi opierać się na regule artystycznej subwersji (czyli na strategii odwróconego porządku, performatywnym działaniu, językowych kalamburach), gdyż ,schizofrenia jest okopem najwyższej jakości” (Fydrych, Dobosz 1989: 25). W grę wchodzi także konstruktywistyczna wizja rzeczywistości i rozumienia władzy. Dlatego tak wymownym planem realizacji postulatów „surrealistycznej rewolucji” staje się ulica, miejsce niepowtarzalnego spektaklu, którego cenną właściwością jest jednorazowość, sprzężona z absurdem i spontanicznością, zdolną porwać przechodniów. Obszar ten jest znaczący również z tego względu, że stanowi przestrzeń zawłaszczenia, która podlega kontroli Wielkiego Brata. Wiąże się ona, podobnie jak we wskazywanym przez Michela de Certeau modelu ,strategii”, z wykształceniem specyficznego typu własności: „zwycięstwem miejsca nad czasem”, opanowaniem go „za pomocą wzroku”, „uznaniem swoistego rodzaju wiedzy” - komplementarnego składnika władzy (de Certeau 2006: 37). Sposobem zerwania (albo, zgodnie z określeniem de Certeau, „nadszarpywania”) strategii jest taktyka (de Certeau 2006: 37), luka w obszarze władzy „widzialnej”. Tę lukę wypełniły České děti, a twórcy „Pomarańczowej Rzeczywistości” dowartościowali ją, wykorzystując perspektywę wędrowca, traktując samo chodzenie jako ,przestrzeń wypowiadania”. De Certeau wspomina o trzech cechach 
owego działania: „teraźniejszości, nieciągłości i fatyczności”12 (de Certeau 2006: 99).

Pomarańczowa Alternatywa, eksplorując potencjał jednorazowości, opierając się na niekontrolowanych działaniach, wymykających się wyraźnym, politycznym deklaracjom, w krótkim czasie dokonała swoistej rewolty w sferze społecznego uczestnictwa. Skromne happeningi szybko zamieniły się w publiczne widowiska, których aktorami byli nie tylko twórcy znani $\mathrm{z}$ artystycznych prowokacji, ale też osoby niezrzeszone, nie mówiąc o (wpisanych w „scenariusz” inscenizacji) funkcjonariuszach MO. Ich rola została skutecznie zakłócona przez działania niekonwencjonalne. Major, rzecznik, pomysłodawca i przywódca Pomarańczowej Alternatywy, ,składający oświadczenie o swojej apolityczności” (,polityce poświęca 80\% rozmowy”; Fydrych, Dobosz 1989: 5), nie był jedynie „hochsztaplerem”, który próbuje ośmieszyć „święty ład”, ale świadomym orędownikiem wolnej twórczości artystycznej (w czasie studiów napisał pracę o społecznym wymiarze sztuki ulicznej). Traktował on happening jako naturalną przestrzeń „człowieka estetycznego” i wskazywał, że „ten sposób myślenia artystycznego nawiązuje do estetyki Marcela Duchampa, podnoszącego przedmiot codziennego użytku do rangi dzieła sztuki" (Fydrych, Dobosz 1989: 29). Figura krasnala stawała się zatem estetycznym ciałem, jak sugerował Fydrych, żywym manifestem, wymykającym się logice reżimu.

Przedmiotami estetycznej gry uczyniono również narzędzia represji, a przede wszystkim hermetyczny język reżimu, zamieniony w surrealistyczny kalambur w myśl zasady Artauda: „na każdym zakręcie myśli Społeczeństwo nas odnajdzie” (Ważyk 1978: 12). Obchody „pomarańczowych” świąt przyciągały uwagę niecodziennymi nazwami, jak choćby „Dzień Terrorysty, czyli Al Fatah”; „Dzień Wojska, czyli Manewry «Melon w majonezie»”; „Kto się boi Papieru Toaletowego?”; „Karnawał RIO-botniczy” (Engelmayer 1990: 26). Slogany były kompilacją propagandowych haseł

${ }^{12}$ Pierwsza z tych cech odnosi się do praw i zakazów, z jakim spotyka się chodzący, i które, jak pisze de Certeau, sam ,urzeczywistnia” wędrówką. Druga wiąże się ze zmiennością użytkowania przestrzeni: „Niektóre miejsca skazuje na bezruch bądź zanik, a innym daje szansę rozwoju i, wraz z innymi, tworzy «rzadkie» przestrzenne «wyrażenia», «przypadkowe» albo nieuzasadnione". Trzecia natomiast odnosi się do pewnej korelacji pomiędzy nabywaniem językowych zdolności komunikacyjnych a „,nauką" chodzenia, poruszania w przestrzeni miejskiej (de Certeau 2006: 99-100). 
lub „słów zakazanych”, opartych na zasadzie subwersji (,Socjalizm to pokój - kapitalizm to dwa pokoje z kuchnią”, „Żądamy kwadratowego stołu”, „Pomścimy Wujka i Ciocię”, „Precz z uPAŁAMI”)". Napisy na transparentach spełniały warunek fatyczności (służyły społecznemu komunikowaniu w warunkach ograniczonej swobody mówienia), wprowadzały w przestrzeń karnawału (a zatem zastępowały język oficjalny absurdalną, teatralną inscenizacją), jednocześnie podważając niezawisłość systemu komunistycznego. Spektakl ten wprowadzał w życie regułę znamienną dla nowego ruchu społecznego, łącząc „,zachowania instrumentalne z ekspresywnymi” (Offe 1995: 231), a więc polityczny gest z aktywnością estetyczną. Funkcjonariusz służb porządkowych symbolizował system, który przekształca się we własną karykaturę. Happeningi Pomarańczowej Alternatywy, zmuszające do „uczestnictwa” reprezentantów reżimu (Dzień Milicjanta, Dzień Tajniaka, Dzień Solidarności z MO), były teatrem maski, podszytym szeroko zakrojoną ironią. Wprawiano funkcjonariuszy w konsternację, podając instrukcję ich udziału w jednorazowym przedstawieniu: „Weź sprzęt do podsłuchu, trąbkę, lejek lub mikrofon. Jeżeli zostaniesz zaproszony do wozu - wchodź! Jest to twoje naturalne miejsce" (Dzień Tajniaka) (Fydrych, Dobosz 1989: 78). Wykształcenie specyficznego, performatywnego modelu komunikacji stało się jednym z kluczy do powodzenia alternatywnych inicjatyw, opartych na materii plastycznej, posługujących się szablonowym językiem. Nie bez powodu pojawiły się odezwy, głoszące, że „wolny uniwersytet jest rewolucją wyobraźni” czy „zakłóceniem symetrii”, a sama rewolucja to „dieta odchudzająca na otłuszczone mózgi” („Pomarańczowa Alternatywa" 1981b: 3).

Jak przypomina Waldemar Kuligowski, powołujący się na teorię Johna Comaroffa, kultura oporu koncentruje się wokół pojęcia władzy, świadomości i intencjonalności (Kuligowski 2012: 31). Jej wyrazem ma być nie

13 Slogany te, wykorzystujące (w formie kontaminacji) lub naśladujące hasła obecne w oficjalnym języku (np. „wędrujące” podczas happeningu „u” w napisie „Precz z uPAŁAMI” czy nawołująca do aktywizacji odezwa „Obywatelu, pomóż milicji, pobij się sam”) jednocześnie uwydatniały kruchość (absurdalność) podstawy, na jakiej się ów system zasadza; łączyły ezopową mowę z elementem prowokacji, bez opowiadania się za jedną z dostępnych politycznych dróg. Pomarańczowa Alternatywa w tym sensie poszukiwała ,innej” drogi do budowania demokratycznego społeczeństwa, dlatego też trudno rozpatrywać działania tego ruchu w kontekście wąsko pojmowanej polityczności, bez uwzględnienia jego artystycznego powinowactwa. 
tylko eksponowana, demonstracyjna postawa, ale także to, co za Umberto Eco można nazwać „semiotyczną partyzantką” (Kuligowski 2012: 31): połączenie symbolu z działaniem wyposażonym w świadomość. Formy kontestacji, kontynuuje polski badacz, ,nie muszą mieć jawnie wywrotowego charakteru" (Kuligowski 2012: 31), wystarczy minimalne zaburzenie przyjętego porządku. Rzecznicy „Zwycięstwa Uśmiechu” sprawnie wykorzystywali w tym celu narzędzia sztuki jako formy pojemnej, pośrednio wskazując na zazębianie się dwóch perspektyw - estetycznej z polityczną. České děti w ten sam sposób ujawniały antydemokratyczny wymiar rzeczywistości, który można odnieść do Rancière’owskiej formuły „dzielenia postrzegalnego", polegającego na ustanawianiu arbitralnych podziałów miejsca w przestrzeni publicznej i narzucaniu wspólnej, normatywnej wizji świata $^{14}$.

„Są różne widoki na Rewolucję” (Fydrych, Dobosz 1989: 102). České děti nie chciały być porównywane z Pomarańczową Alternatywą; szczegółowe różnice (cele operacyjne) między obiema formami protestu pozwalają dostrzec odrębność obu ruchów społecznych. Związkiem, którego jednak nie można zignorować, jest ,poetyka” tych grup (używając antropologicznej nomenklatury przywoływanego przez Kuligowskiego Jamesa Scotta - ,grup relatywnie pozbawionych władzy”), oparta na „orężu słabych”: „wleczeniu się noga za nogą", ,symulacji”, „dezercji”, „udawanej pokorze” (Kuligowski 2012: 36), mowie ulicy w znaczącej mierze warunkowanej artystycznym rodowodem jej „użytkowników”. Hradilková mówi o piętnie „don kichotów” czy „garstce głupców”, Placák o tych, którzy będą „mimo chápání establishmentu”, Fydrych o „Mężach Pomarańczowych”, w sytuacji, gdy ,nigdy rzeczywistość nie była tak bliska surrealizmu” (Fydrych, Dobosz 1989: 97). Co istotne po 1989 roku członkowie omawianych ugrupowań albo tracili popularność (jak Major ${ }^{15}$ ), albo też sami wątpili w możliwość kontynuowania dotychczasowych form społecznego zaangażowania. Topol na przykład swoją Balladę... zakończył ironicznie: „A ted' si sedíme

14 J. Rancière definiuje ,dzielenie postrzegalnego” jako „system odczuwalnych pewników, które uwidaczniają istnienie tego, co wspólne, jak i podziałów, definiujących w jego obrębie poszczególne miejsca oraz części. Dzielenie postrzegalnego ustanawia to, co jest współdzielone, i jego odrębne części” (Rancière 2008: 69).

15 Ze względu na zmianę warunków społeczno-politycznych po 1989 roku, która jednocześnie wiązała się z mniejszą siłą natężenia działań Pomarańczowej Alternatywy. 
/ na pobřeží rozumu / pod slunečníkem pověry / a svátku / čekáme na zlatou rybičku / na její moudrost / a na její zlatku”, twierdząc wprost, że „underground istnieje w Chinach albo w Wietnamie, (...) ale nie tutaj ani nie w Stanach" (za: Engelking 2001: 93). Być może na tym polega błogosławieństwo i przekleństwo „surrealistycznej” teraźniejszości.

\section{Literatura}

Burszta W.J., 2005, Kontrkultura - mit zdegradowany?, w: Kontrkultura. Co nam z tamtych lat?, red. W.J. Burszta, M. Czubaj, M. Rychlewski, Warszawa, s. 218-222.

Čapek K., 1984, Marsyas čili na okraji literatury, Praha.

de Certeau M., 2006, Wynaleźć codzienność. Sztuki działania, przeł. M. Łukasiewicz, Warszawa.

Engelking L., 2001, Surrealizm, underground, postmodernizm. Szkice o literaturze czeskiej, Łódź.

Engelmayer A., 1990, „Żądamy wypaczeń bez socjalizmu!”. Historia Pomarańczowej Alternatywy, czyli rzecz o surrealizmie socjalistycznym, „Polska Sztuka Ludowa Konteksty" z. 2, s. 20-26.

Foucault M., 1993, Nadzorować i karać. Narodziny więzienia, przeł. T. Komendant, Warszawa.

Fydrych W., Dobosz B., 1989, Hokus-pokus, czyli Pomarańczowa Alternatywa, Wrocław.

Jirous I.M., 1988, Petice za prošetření všech okolností smrti Pavla Wonky, <http://www. totalita.cz/txt/txt_o_wonkap_petice.php>, 20.06.2013.

Kenney P., Rewolucyjny karnawat. Europa Środkowa 1989, przeł. P. Szymor, Wrocław 2005.

„Koruna” 1989a, nr 1, <http://www.vons.cz/data/pdf/Koruna/koruna_1.pdf>, 19.02.2014. „Koruna” 1989b, nr 2, <http://www.vons.cz/data/pdf/Koruna/koruna_1.pdf>, 19.02.2014. „Koruna” 1989c, nr 3, <http://www.vons.cz/data/pdf/Koruna/koruna_1.pdf>, 19.02.2014. Kuligowski W., 2012, Od „rytuałów buntu” do „etnografii wojującej”. Kategoria sprzeciwu w teorii antropologicznej, w: Oblicza buntu. Praktyki i teorie sprzeciwu w kulturze współczesnej, red. W. Kuligowski, A. Pomieciński, Poznań, s. 19-45.

Offe C., 1995, Nowe ruchy spoleczne: przekraczanie granic polityki instytucjonalnej, w: Władza i spoleczeństwo: Antologia tekstów z socjologii polityki, red. J. Szczupaczyński, Warszawa, s. 226-233.

Placák P., 1989, Bohemorum liberorum declaratio, „Koruna” nr 2, <http://www.vons.cz/ data/pdf/Koruna/koruna_2.pdf>, 19.02.2014. 
Placák P., 2006, Do politiky? Jen jako podkoní Jeho Veličenstva!, <http://hn.ihned.cz/c1-18492240-petr-placak-do-politiky-jen-jako-podkoni-jeho-velicenstva>, 26.06.2013.

Placák P., 2007, Fízl, Praha.

Placák P., 2012, Demonstrace jsem si užival, rozm. przepr. V. Poláček, „Plzenský deník” $\mathrm{nr} 11,<\mathrm{http}: / /$ plzensky.denik.cz/zpravy_region/demonstrace-jsem-si-uzival-rika-petr-placak-20121118.html>, 23.06.2013.

„Pomarańczowa Alternatywa”, 1981a, nr 1, <http://archiwa-przyszlosci.bzzz.net/tlumaczenia/pomaranczowa_alt.html\#pomarancz1>, 26.06.2013.

„Pomarańczowa Alternatywa”, 1981b, nr 7, <http://archiwa-przyszlosci.bzzz.net/tlumaczenia/pomaranczowa_alt.html\#pomaranczl>, 26.06.2013.

Rancière J., 2008, Dzielenie postrzegalnego. Estetyka i polityka, przeł. M. Kropiwnicki, J. Sowa, Kraków.

Svodobová J. (red.), 1995, Nezávislá skupina České děti (1988-1989). Dokumenty. Česká společnost v obdobi normalizace za revoluce 1969-1989). Materiály, studie, dokumenty 3, Praha.

Topol J., 1997, Balada o neztracený generaci, „Revolver Revue” nr 36, <http://www. revolverrevue.cz/balada-o-neztraceny-generaci>, 23.06.2013.

Warda J., 2010, Wrocławskie krasnoludki, <http://kulturaenter.pl/wroclawskie-krasnoludki/2-010/01/>, 29.06.2013.

Ważyk A. (red.), 1978, Surrealizm. Teoria i praktyka literacka. Antologia, przeł. A. Ważyk, Warszawa.

Włodarczyk W., 1989, Sztuka polska w latach 1950-1954, Paryż. 
